\title{
Carboxylic Acids and Esters as Scaffold for Cavities in Porous Single Layer Anti-Reflective Coatings of Silica-Titania with Excellent Optical and Mechanical Properties
}

\author{
Elisabete H. S. de C. Menezes' ${ }^{1}$ Peter König', Mohammad Hussein Jilavi², \\ Peter William de Oliveira ${ }^{2}$, Severino Alves Júnior ${ }^{1}$ \\ ${ }^{1}$ Department of Fundamental Chemistry, Federal University of Pernambuco, Recife, Brazil \\ ${ }^{2}$ INM Leibniz-Institute for New Materials, Saarbrücken, Germany \\ Email: elisabetehmenezes@yahoo.com.br
}

Received 28 June 2014; revised 31 July 2014; accepted 9 August 2014

Copyright (C) 2014 by authors and Scientific Research Publishing Inc.

This work is licensed under the Creative Commons Attribution International License (CC BY). http://creativecommons.org/licenses/by/4.0/

(c) (i)

\begin{abstract}
Anti-reflective (AR) single layer of silica-titania $\left(\mathrm{SiO}_{2}-\mathrm{TiO}_{2}\right)$ coatings were obtained from sols containing pyromellitic dianhydride (PMDA) derivatives and Ti and Si precursors on glass substrate by dip-coating method. The coatings showed very high optical quality and the transmission was improved to up to $\mathbf{9 8 . 5 \%}$. Furthermore, the coatings also presented good mechanical stability.
\end{abstract}

\section{Keywords}

Anti-Reflective Coating, Pyromellitic Dianhydride, Silica, Titania, $\mathrm{SiO}_{2}, \mathrm{TiO}_{2}$

\section{Introduction}

Anti-reflective coatings (ARCs) are of huge interest in particular for solar cell producers in order to avoid loss of sunlight (energy) due to reflections on untreated glass [1]-[9]. These coatings can be produced by different techniques as physical or chemical vapor deposition (PVD and CVD, respectively) and sol-gel methods. However, the vacuum facilities associated with the first two methods lead to immense production costs, especially when large substrates areas are used. To avoid this, a wet chemical method like sol-gel is used as cost-effective method to produce ARCs.

How to cite this paper: de C. Menezes, E.H.S., König, P., Jilavi, M.H., de Oliveira, P.W. and Júnior, S.A. (2014) Carboxylic Acids and Esters as Scaffold for Cavities in Porous Single Layer Anti-Reflective Coatings of Silica-Titania with Excellent Optical and Mechanical Properties. Materials Sciences and Applications, 5, 783-788. http://dx.doi.org/10.4236/msa.2014.511078 
In general, high quality ARCs are produced by multilayers coating technique, but this is a time-consuming and costly method especially because of thermal curing process. In this context, single layer ARCs obtained by sol-gel method emerge as a technically viable and economically advantageous alternative since these films present broadband transmission, which is needed for solar spectrum; can be produced in large amounts and can be applied to a large area of the substrate by using industrial scale technology. Due to these reasons, it has been shown in the last decades that industries prefer a single layer ARC when large areas of substrate and large consume are involved, like in solar cell companies.

The usual way to generate a single layer ARC on a glass substrate is producing a porous $\mathrm{SiO}_{2}$ layer by sol-gel method using polymers as porogen [1] [4] [10]-[13]. The porosity (air) of the layer reduces the refractive index from 1.5 for normal float glass to a region of $1.1-1.45$, depending on the fraction of porosity and the techniques of preparation of $\mathrm{SiO}_{2}$ matrix.

For the use of an ARC on solar cells, a self cleaning ability as second property is also important. For this purpose $\mathrm{TiO}_{2}$ has been proven to be a very suitable material, and to overcome its drawback of a high refractive index, again the porosity of the coating plays an important role [3] [5] [6] [8] [14].

Although porosity is responsible for the optical properties of AR coating, the presence of pores usually implies low mechanical stability, which can be perceived, for example, in the poor adhesion of the films to the substrate and poor scratch resistance [1] [15].

Herein, a novel method is presented to obtain porous single layer $\mathrm{ARCs}$ of $\mathrm{SiO}_{2}-\mathrm{TiO}_{2}$ with good mechanical properties and photocatalytic activity by using $\mathrm{Ti}$ and Si precursors and acid or diacids/diesters pyromellitic dianhydride (PMDA) derivatives as scaffold for cavities formation in the final structure of the $\mathrm{SiO}_{2}-\mathrm{TiO}_{2}$ coating.

\section{Experimental}

\subsection{Preparation of Ti Precursor (Solution A)}

$\mathrm{TiCl}_{4}(6.67 \mathrm{ml})$ was carefully added to ultrapure water $(25.0 \mathrm{ml})$ at $5^{\circ} \mathrm{C}$ and stirred for 30 minutes until the obtention of a clear and colorless solution.

\subsection{Preparation of Sols}

Sol 1. PMDA (2.73 g, $12.5 \mathrm{mmol})$ and ultrapure water $(225 \mathrm{mg}, 12.5 \mathrm{mmol})$ were added to a solution of isopropanol/n-butanol (iPrOH/n-BuOH, $50.0 \mathrm{ml}, 1: 1 \mathrm{v} / \mathrm{v}$ ) and stirred for 48 hours at room temperature. In such conditions, the PMDA may undergo nucleophilic ring opening reactions. Then, an aliquot of the obtained solution $(5.00 \mathrm{ml})$, TEOS $(1.30 \mathrm{~g}, 6.25 \mathrm{mmol})$ and an aliquot of solution A $(0.16 \mathrm{ml})$ were added under stirring and in this order to a solution of $\mathrm{iPOH} / \mathrm{n}-\mathrm{BuOH}(25.0 \mathrm{ml}, 1: 1 \mathrm{v} / \mathrm{v})$. The mixture was stirred at room temperature for 6 hours.

Sol 2. PMDA ( $2.18 \mathrm{~g}, 10.0 \mathrm{mmol})$ and ultrapure water $(0.36 \mathrm{~g}, 20.0 \mathrm{mmol})$ were added to THF $(22.5 \mathrm{ml})$ and stirred for 48 hours at room temperature, then an aliquot of this solution $(2.82 \mathrm{~g})$, TEOS $(1.30 \mathrm{~g}, 6.25 \mathrm{mmol})$ and an aliquot of solution $\mathrm{A}(0.16 \mathrm{ml})$ were added under stirring and in this order to a solution of $\mathrm{PrOH} / \mathrm{n}-\mathrm{BuOH}$ $(25.0 \mathrm{ml}, 1: 1 \mathrm{v} / \mathrm{v})$ and the mixture was stirred at room temperature for 6 hours.

\subsection{Preparation of ARC-1 and ARC-2}

ARC-1 and ARC-2 (from the sols 1 and 2, respectively) were prepared by dip-coating deposition method onto microscope glass slides at the withdrawal speeds of $4 \mathrm{~mm} / \mathrm{s}$ and thermally treated at $500^{\circ} \mathrm{C}$ for 2 hours in air.

\section{Results and Discussion}

For all AR-coated substrates, the anti-reflective effect was obvious by visual inspection and the excellent optical properties of the obtained coatings are confirmed by optical transmission and reflection measurements (Figure 1 and Figure 2, respectively) performed by using a Cary 5000 UV-Vis-NIR Spectrophotometer (Agilent Technologies). In the visible range of light a significant improvement of up to $7.7 \%$ for the transmission was observed and the reflection could be reduced to less than $2 \%$. ARC-1 deserves special attention, since it showed a peak transmission of up to $98 \%$ and reflection lower than $2 \%$.

The thicknesses and refractive indices (at $547 \mathrm{~nm}$ ) of ARC-1 and ARC-2 were determined with an M-2000 DI, Spectroscopic Ellipsometer (J. A. Woollam Co., Inc.). The thicknesses of ARC-1 and ARC-2 were equal to 72 


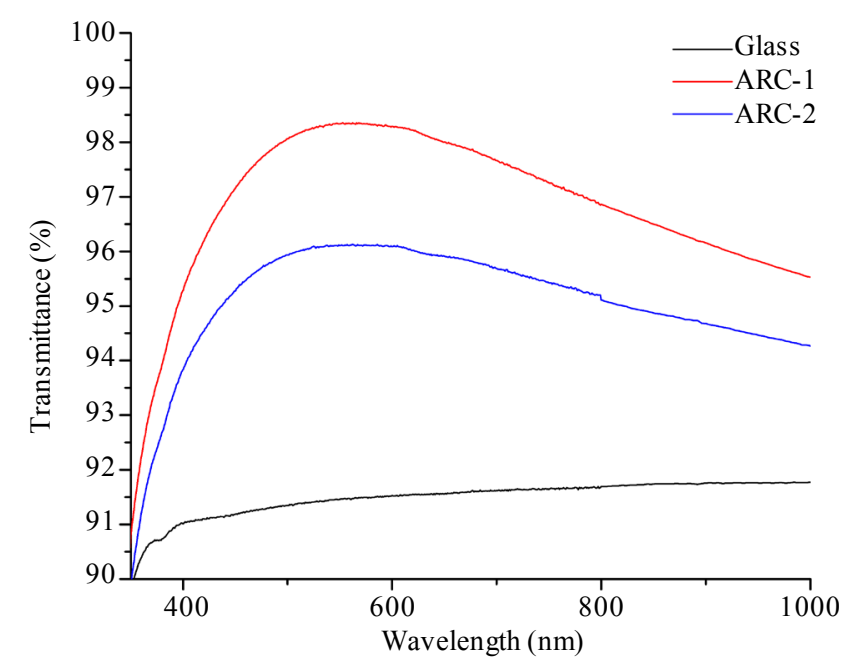

Figure 1. Transmittance of ARC-1 and ARC-2.

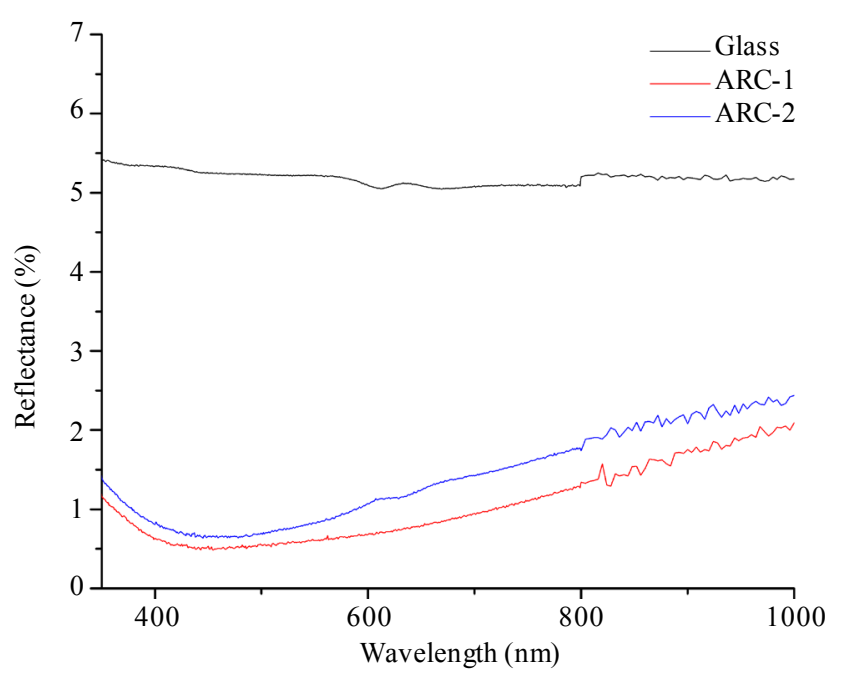

Figure 2. Reflectande of ARC-1 and ARC-2.

and $88 \mathrm{~nm}$, respectively, and their correspondent refractive indices were equal to 1.3258 and 1.4090. Thus, in spite of the incorporation of $\mathrm{TiO}_{2}$ within ARC-1 and ARC-2, their refractive indices were reduced to values less than the ones of glass.

The morphology and microstructure of ARC-1 and ARC-2 were accomplished by using a JEOL 7500F High Resolution Scanning Electron Microscope (HRSEM) and their micrographs of top views at low $(10,000 \times)$ and high $(50,000 \times)$ magnification are shown in Figure 3. ARC-1 HRSEM micrographs (Figure 3(a) and Figure 3(b)) indicated a high porous microstructure and pore sizes between 50 to $200 \mathrm{~nm}$. For ARC-2, the HRSEM micrographs (Figure 3(c) and Figure 3(d)) demonstrated that it was less porous than ARC-1 and that their pore sizes were between $100-200 \mathrm{~nm}$, but it seems that the pores joint each other locally to produce a crack-like microstructure.

In order to investigate their mechanical stability, specifically their scratch resistances (or hardnesses) and their adhesions to the glass substrates, ARC-1 and ARC-2 were submitted to standard tests, namely Pencil Test ASTM D3363-05) [16] and Tape Test (ASTM 3359 Method B) [17] respectively. For ARC-1, the hardness was equal to $1 \mathrm{H}$ (Figure 4(a)) and for ARC-2, the determined hardnesses was equal to $8 \mathrm{H}$ (Figure 4(b)), which is the second highest rating on pencil hardness grade. The adhesion test showed that the coatings interact very well with the glass surface and no cracks propagate from the testing lines into the films (Figure 5(a) and Figure 5(b)). Also for the adhesion test, crosshatch tape test did not remove parts of the coatings. A value equal to 5 


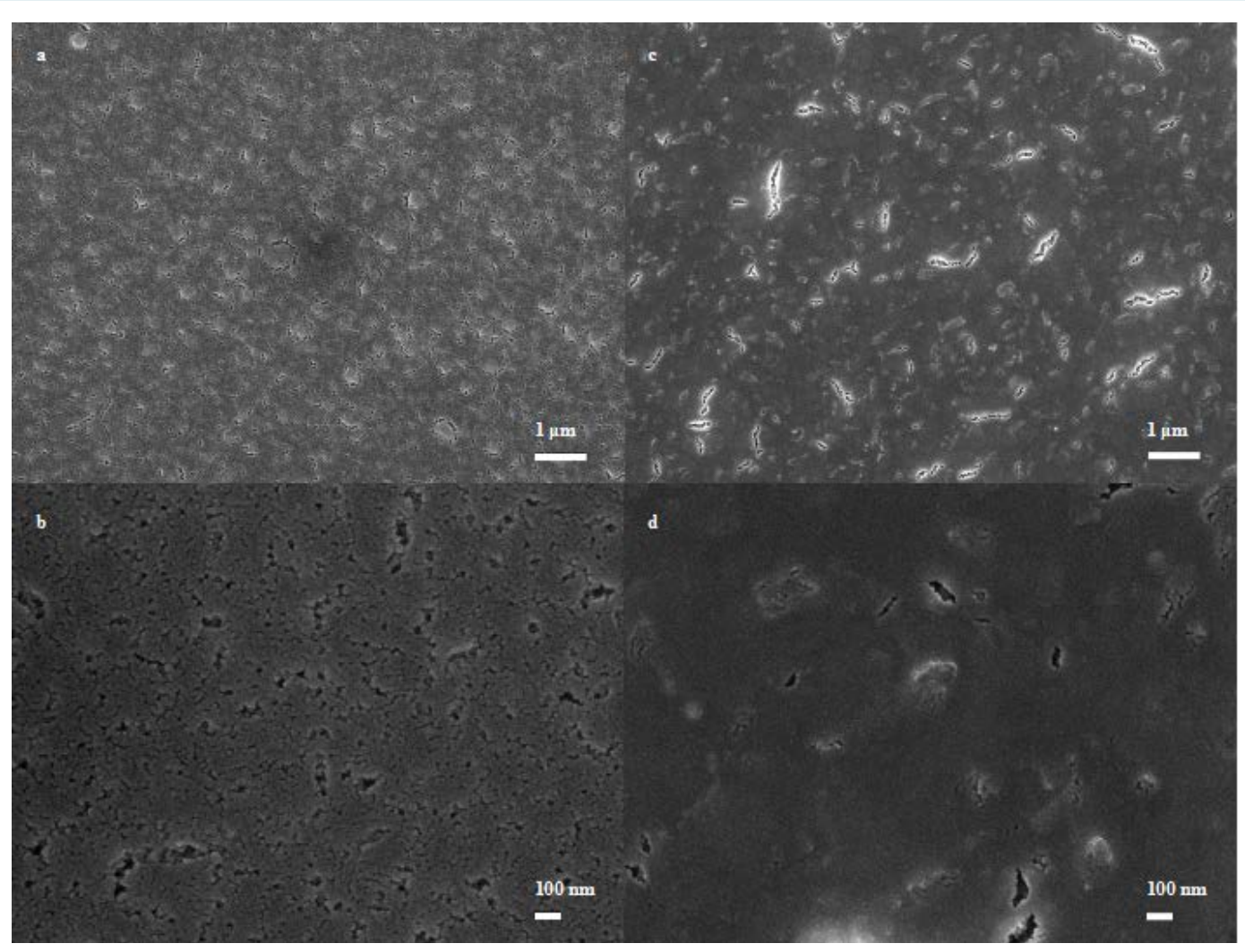

Figure 3. HRSEM micrographs of ARC-1 ((a) and (b)) and ARC-2 ((c) and (d)).

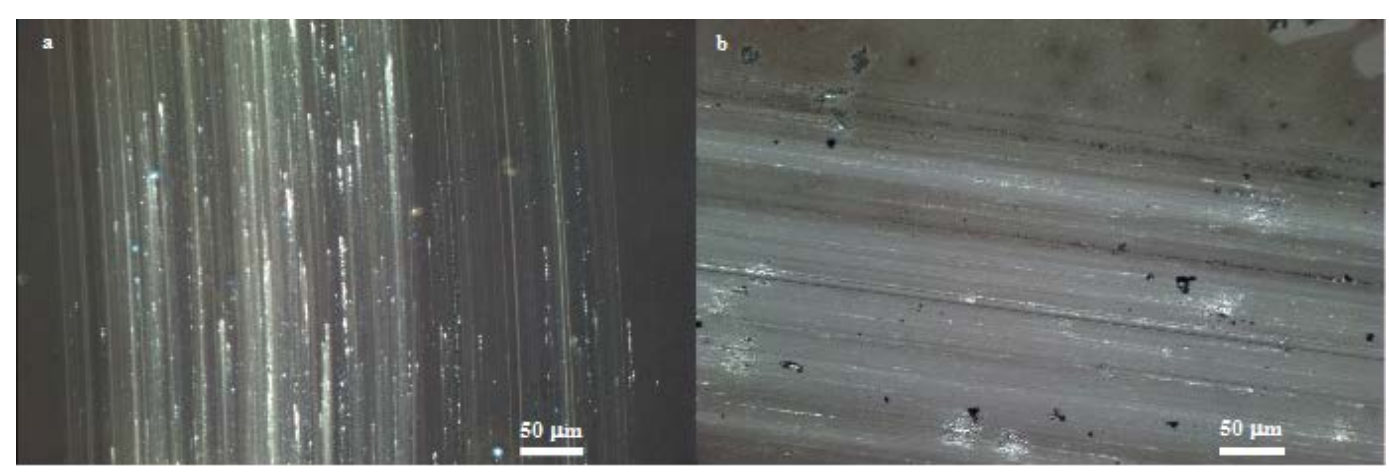

Figure 4. Scratched areas of ARC-1 with $1 \mathrm{H}$ pencil (a) and of ARC with $8 \mathrm{H}$ pencil (b).
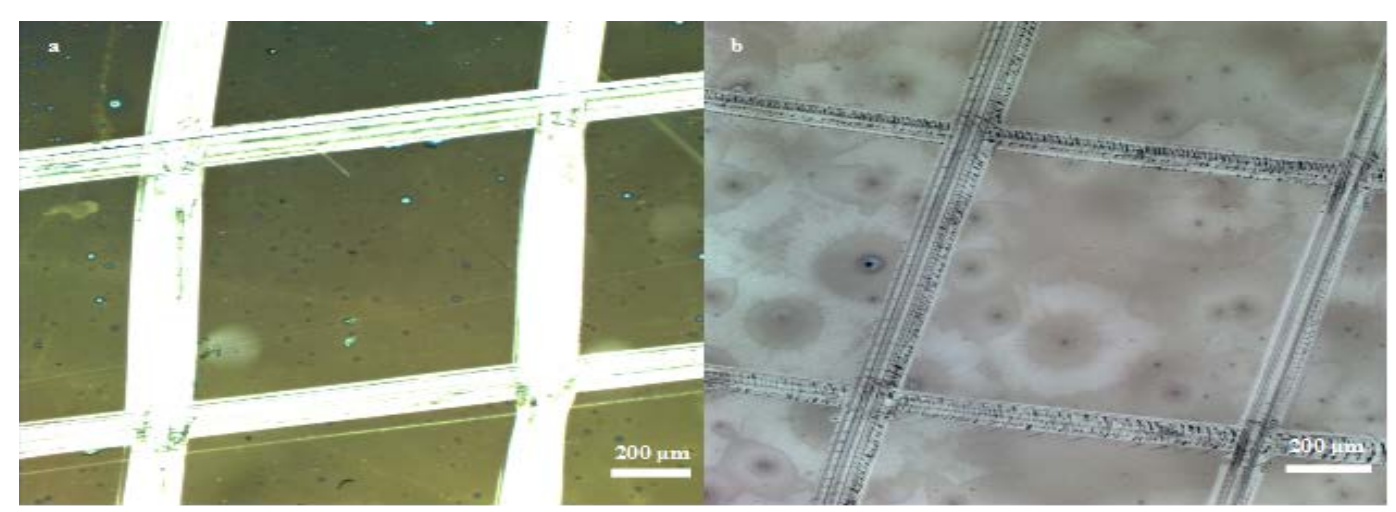

Figure 5. Crosshatched test areas of ARC-1 (a) and of ARC-2 (b). 
(this means $100 \%$ adhesion by crosshatch and $100 \%$ adhesion after tape test on the crosshatched test area) was observed for ARC-2 and a value of 4 was obtained for ARC-1. Since generally, for porous films, transmittance and scratch resistance play against each other, these results can confirm that ARC-1 include higher fraction of porosity than ARC-2. However, ARC-1 and ARC-2 showed comparable or even higher transmittance values and also higher scratch resistances and adhesions ratings in comparison to others single layer ARCs found in literature [1] [15] [18] [19], which suggests that ARC-1 and ARC-2 are more efficient when it is necessary to combine anti-reflective properties and mechanical stability, demonstrating the pertinence of the proposed method.

Moreover, it was verified that films prepared by the presented method also showed photocatalytic activity against methyl violet. After 10 hours of irradiation by using a simulated sunlight irradiator, it was verified a photodegradation efficiency up to $97 \%$.

\section{Conclusions}

ARC-1 and ARC-2 showed significant improvement for transmittance and also high adhesion and scratch resistance as well as photocatalytic activity. The use of organic ligand such as carboxylic acids or diacids/diesters opens a wide range of possibilities for the formation of ARCs and tailoring the pore sizes with different organic ligands seems to be a potential way to achieve defined pore sizes in the final coating.

\section{Acknowledgements}

The authors gratefully acknowledge the financial support of the Brazilian research funding agency CNPq and the Coordination for the Improvement of Higher Education Personnel (CAPES). The authors are also thankful to the Institute of Nanotechnology for Integrated Markers-INCT-INAMI.

\section{References}

[1] Batista, M.C. and Morales, A. (2003) Silica Antireflective Films on Glass Produced by the Sol-Gel Method. Solar Energy Materials and Solar Cells, 80, 217-225. http://dx.doi.org/10.1016/j.solmat.2003.06.004

[2] Schüler, A., Dutta, D., de Chambrier, E., Roecker, C., Temmerman, G.D., Oelhafen, P. and Scartezzini, J.-L. (2006) Sol-Gel Deposition and Optical Characterization of Multilayered $\mathrm{SiO}_{2} / \mathrm{Ti}_{1-x} \mathrm{Si}_{x} \mathrm{O}_{2}$ Coatings on Solar Collector Glasses. Solar Energy Materials and Solar Cells, 90, 2894-2907. http://dx.doi.org/10.1016/j.solmat.2006.05.003

[3] Zhang, X., Fujishima, A., Jin, M., Emeline, A.V. and Murakami, T. (2006) Double-Layered $\mathrm{TiO}_{2}-\mathrm{SiO}_{2} \mathrm{Nanostructured}$ Films with Self-Cleaning and Antireflective Properties. The Journal of Physical Chemistry B, 110, 25142-25148. http://dx.doi.org/10.1021/jp064442u

[4] Kim, S., Cho, J. and Char, K. (2007) Thermally Stable Antireflective Coatings based on Nanoporous Organosilicate Thin Films. Langmuir, 23, 6737-6743. http://dx.doi.org/10.1021/la070003q

[5] Wang, X. and Shen, J. (2010) Sol-Gel Derived Durable Antireflective Coating for Solar Glass. Journal of Sol-Gel Science and Technology, 53, 322-327. http://dx.doi.org/10.1007/s10971-009-2095-y

[6] Cannavale, A., Fiorito, F., Manca, M., Tortotici, G., Cingolani, R. and Gigli, G. (2010) Multifunctional Bioinspired Sol-Gel Coatings for Architectural Glasses. Building and Environment, 45, 1233-1243. http://dx.doi.org/10.1016/j.buildenv.2009.11.010

[7] Addamo, M., Augugliaro, V., Paola, A.D., Garcia-Lopez, E., Loddo, V., Marci, G. and Palmisano, L. (2008) Photocatalytic Thin Films of $\mathrm{TiO}_{2}$ Formed by a Sol-Gel Process Using Titanium Tetraisopropoxide as the Precursor. Thin Solid Films, 516, 3802-3807. http://dx.doi.org/10.1016/j.tsf.2007.06.139

[8] Liu, Z., Zhang, X., Murakami, T. and Fujishima, A. (2008) Sol-Gel $\mathrm{SiO}_{2} / \mathrm{TiO}_{2}$ Bilayer Films with Self-Cleaning and Antireflection Properties. Solar Energy Materials and Solar Cells, 92, 1434-1438. http://dx.doi.org/10.1016/j.solmat.2008.06.005

[9] Kesmez, Ö., Çamurlu, H.E., Burunkaya, E. and Arpaç, E. (2009) Sol-Gel Preparation and Characterization of AntiReflective and Self-Cleaning $\mathrm{SiO}_{2}-\mathrm{TiO}_{2}$ Double-Layer Nanometric Films. Solar Energy Materials and Solar Cells, 93, 1833-1839. http://dx.doi.org/10.1016/j.solmat.2009.06.022

[10] Nguyen, C.V., Carter, K.R., Hawker, C.J., Hedrick, J.L., Jaffe, R.L., Miller, R.D., Remenar, J.F., Rhee, H.W., Rice, P.M., Toney, M.F., Trollsas, M. and Yoon, D.Y. (1999) Low-Dielectric, Nanoporous Organosilicate Films Prepared via Inorganic/Organic Polymer Hybrid Templates. Chemistry of Materials, 11, 3080-3085. http://dx.doi.org/10.1021/cm990114d

[11] Lee, B., Oh, W., Yoon, J., Hwang, Y., Kim, J., Landes, B.G., Quintana, J.P. and Ree, M. (2005) Scattering Studies of 
Nanoporous Organosilicate Thin Films Imprinted with Reactive Star Porogens. Macromolecules, 38, 8991-8995. http://dx.doi.org/10.1021/ma0501951

[12] Falcaro, P., Malfatti, L., Kidchob, T., Giannini, G., Falqui, A., Casula, M.F., Amenitsch, H., Marmiroli, B., Grenci, G. and Innocenzi, P. (2009) Hierarchical Porous Silica Films with Ultralow Refractive Index. Chemistry of Materials, 21, 2055-2061.

[13] Guillemot, F., Brunet-Bruneau, A., Bourgeat-Lami, E., Gacoin, T., Barthel, E. and Boilot, J.P. (2010) Latex-Templated Silica Films: Tailoring Porosity to Get a Stable Low-Refractive Index. Chemistry of Materials, 22, 2822-2828.

[14] Mellott, N.P., Durucan, C., Pantano, C.G. and Guglielmi, M. (2006) Commercial and Laboratory Prepared Titanium Dioxide Thin Films for Self-Cleaning Glasses: Photocatalytic Performance and Chemical Durability. Thin Solid Films, 502, 112-120. http://dx.doi.org/10.1016/j.tsf.2005.07.255

[15] Budunoglu, H., Yildirim, A. and Bayindir, M. (2012) Flexible and Mechanically Stable Antireflective Coatings from Nanoporous Organically Modified Silica Colloids. Journal of Materials Chemistry, 22, 9671-9677. http://dx.doi.org/10.1039/c2jm30804e

[16] ASTM International (2005) Standard Test Method for Film Hardness by Pencil Test, ASTM D3363-05. West Conshohocken.

[17] ASTM International (2009) Standard Test Methods for Measuring Adhesion by Tape Test, ASTM D3359-09e2. West Conshohocken.

[18] Chen, C.H., Li, S.Y., Chiang, A.S., Wu, A.T. and Sun, Y. (2011) Scratch-Resistant Zeolite Anti-Reflective Coating on Glass for Solar Applications. Solar Energy Materials and Solar Cells, 95, 1694-1700. http://dx.doi.org/10.1016/i.solmat.2011.01.032

[19] Pan, Q., Shen, J., Wang, X. and Zhang, Z. (2011) Antireflective Coatings for Solar Cells Derived from Different Evaporation Solvents. Proceedings of the 5th Shangai International Nanotechnology Cooperation Symposium, Shangai, 30 October-1 November 2011, 10-14. 
Scientific Research Publishing (SCIRP) is one of the largest Open Access journal publishers. It is currently publishing more than 200 open access, online, peer-reviewed journals covering a wide range of academic disciplines. SCIRP serves the worldwide academic communities and contributes to the progress and application of science with its publication.

Other selected journals from SCIRP are listed as below. Submit your manuscript to us via either submit@scirp.org or Online Submission Portal.
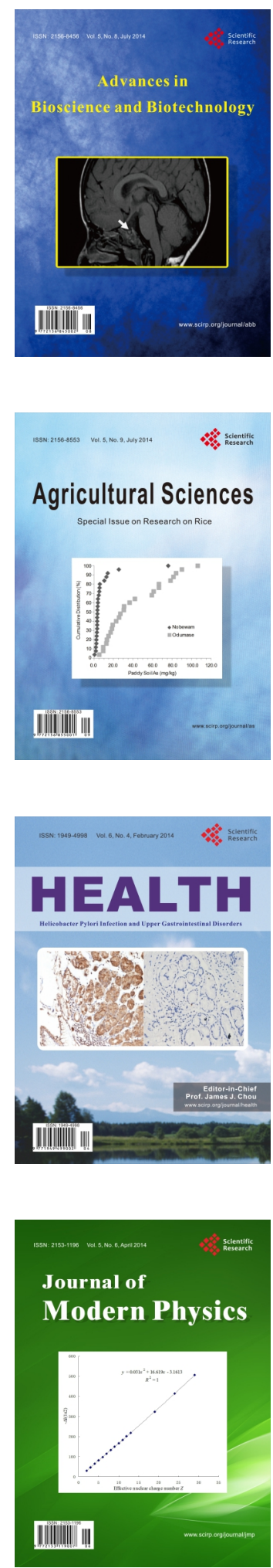
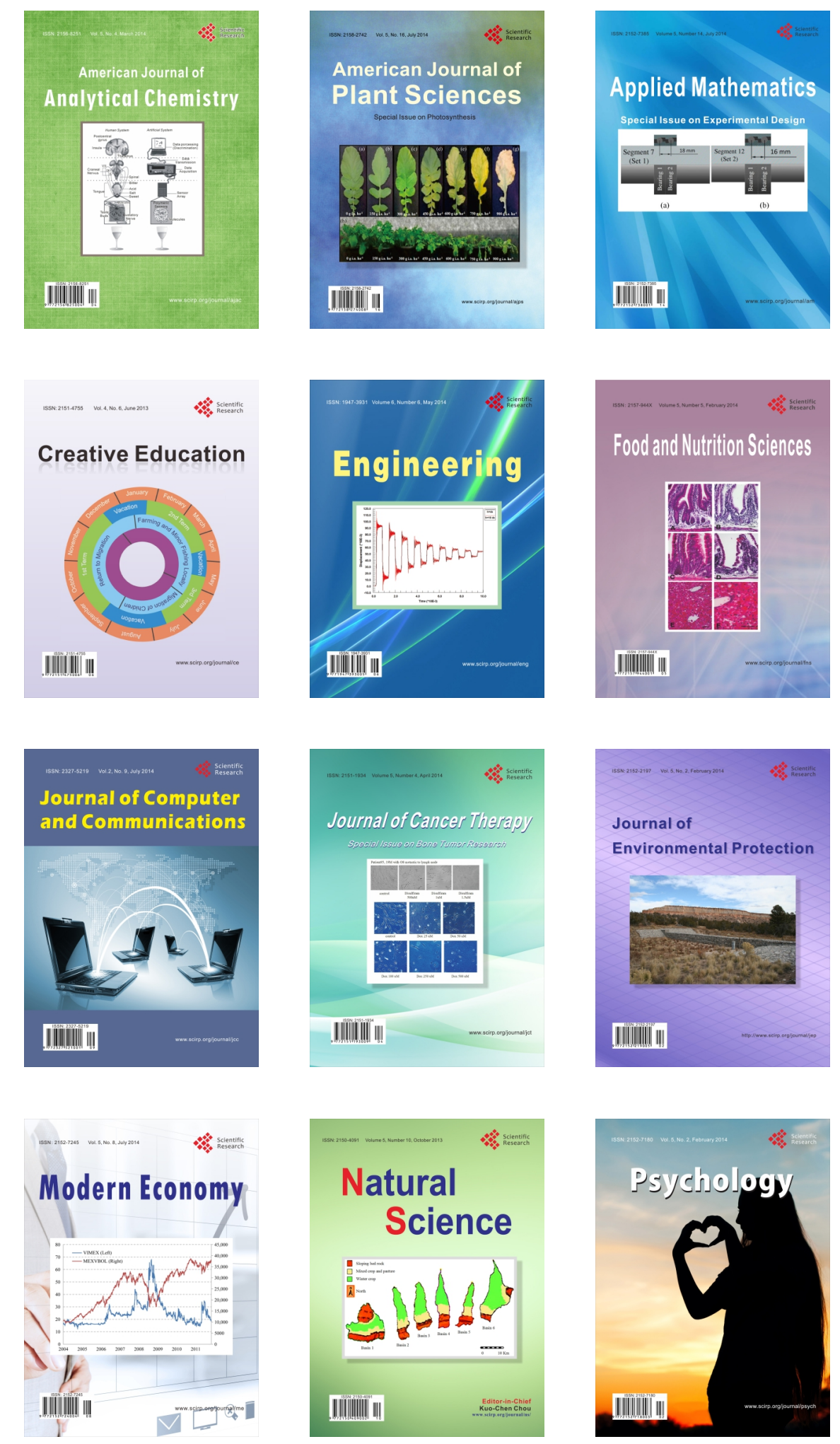